\title{
Submerged fermentation production and characterization of intracellular triterpenoids from Ganoderma lucidum using HPLC-ESI-MS*
}

\author{
Mei-lin CUI, Huan-yi YANG, Guo-qing $\mathrm{HE}^{\dagger *}$ \\ (Zhejiang Provincial Key Laboratory of Food Microbiology, College of Biosystems Engineering and Food Science, \\ Zhejiang University, Hangzhou 310058, China) \\ †E-mail: gqhe@zju.edu.cn \\ Received June 17, 2015; Revision accepted Aug. 4, 2015; Crosschecked Nov. 11, 2015
}

\begin{abstract}
As the main bioactive metabolites of Ganoderma lucidum, triterpenoids have various pharmacological effects. In this paper, the nutritional requirements and culture conditions of a submerged culture of G. Iucidum were optimized using the response surface methodology; maximum mycelia biomass and intracellular triterpenoid production reached $1.87 \mathrm{~g} / 100 \mathrm{ml}$ and $93.21 \mathrm{mg} / 100 \mathrm{ml}$, respectively, for a culture consisting of wort $4.10 \%(0.041 \mathrm{~g} / \mathrm{ml})$ and yeast extract $1.89 \%(0.0189 \mathrm{~g} / \mathrm{ml}), \mathrm{pH} 5.40$. For the first time, we established that wort, which is cheap and abundant, can replace the more commonly used glucose as the sole source of carbohydrate. Using high-performance liquid chromatography-electrospray ionization-mass spectrometry (HPLC-ESI-MS), 10 major ganoderic acids were tentatively identified based on the predominant fragmentation pathways with the elimination of $\mathrm{H}_{2} \mathrm{O}$ and $\mathrm{CO}_{2}$, as well as cleavage of the D-ring.
\end{abstract}

Key words: Ganoderma lucidum, Wort, Response surface methodology, Ganoderic acids, HPLC-ESI-MS doi: 10.1631 /jzus.B1500147

Document code: A

CLC number: Q815

\section{Introduction}

Ganoderma lucidum (Leyss. ex Fr.) Karst ("Lingzhi" in Chinese, "Youngzhi" in Korean, and "Reishi" in Japanese), a fungus belonging to the family of Polyporaceae, is a valuable traditional Chinese medicinal mushroom with a history of use spanning 2000 years. All its parts, including fruiting bodies, mycelia, and spores, can be used for medicinal purposes, and have been involved in the clinical prevention and treatment of a wide range of diseases (Shiao, 2003), such as tumors (Tang and Zhong, 2004; Thyagarajan et al., 2010), insomnia, hepatitis (Paterson, 2006), cardiovascular diseases, hypertension

\footnotetext{
Corresponding author

* Project supported by the National Natural Science Foundation of China (No. 31130042)

(1) ORCID: Guo-qing HE, http://orcid.org/0000-0002-1177-8016

(c) Zhejiang University and Springer-Verlag Berlin Heidelberg 2015
}

(Fang et al., 2002; Liu and Zhang, 2005), hyperglycaemia, diabetes, inflammation, immune diseases, and human immunodeficiency virus type 1 (HIV-1) (Min et al., 1998; Wasser, 2010). The pharmaceutically active compounds of G. lucidum include polysaccharides, triterpenoids, lactones, nucleotides, steroids, alkaloids, peptides, and fatty acids, among which the polysaccharides and triterpenoids are the major sources of biological activity and are responsible for some of these medicinal properties (Qiao et al., 2007; Keypour et al., 2010).

Traditionally, G. lucidum is cultivated in the field, which takes a long time and cannot guarantee standardized products and high yield (Fang and Zhong, 2002b). Bioactivity is much higher in mycelia than in fruiting bodies and spores. Therefore, submerged fermentation has been a promising method for efficient and large-scale production of mycelia biomass and bioactive metabolites with a shortened 
time of incubation and reduced risk of contamination (Kim et al., 2004; Lin and Yang, 2006). Bioactive metabolites are influenced by different culture conditions ( $\mathrm{Xu}$ et al., 2010) and the aim of condition optimization is to accelerate mycelia growth and enhance productions of triterpenoids and polysaccharides (Wagner et al., 2003; Tang et al., 2009; Zhang and Zhong, 2010). Most research to date has focused on increasing mycelia yield and the production of polysaccharides (Wagner et al., 2004; Kim et al., 2006; Liu and Zhong, 2011). The production of triterpenoids by fermentation using wort as a cheap carbon source instead of glucose has not been optimized, even though triterpenoids are the most important contributor to the bioactivity and quality of $G$. lucidum (Tang et al., 2006; Zhao et al., 2011; Wu et al., 2012).

High-performance liquid chromatography (HPLC) has been widely used for isolation and purification of triterpenoids from crude extracts of G. lucidum (Tang et al., 2006; Keypour et al., 2010), while LC-mass spectrometry is the most efficient method for characterizing triterpenoid compounds (Yang et al., 2007; Ding et al., 2010; Guo et al., 2013). Ganoderic acids are the main constituents of triterpenoids and to date, more than 200 ganoderic acid derivatives and other triterpenic acids have been identified from the fruiting bodies, spores, and mycelia (Ma et al., 2014); the structural identification of ganoderic acid derivatives is needed for research into their pharmacological effects.

In this study, the nutritional requirements and culture conditions for submerged fermentation of G. lucidum were optimized for mycelia yield and production of intracellular triterpenoids using response surface methodology. The major compounds of triterpenoids were then characterized by highperformance liquid chromatography-electrospray ionization multi-stage tandem mass spectrometry (HPLC$\mathrm{ESI}^{-M S}{ }^{n}$ ).

\section{Materials and methods}

\subsection{Microorganism and culture conditions}

In a preliminary experiment, we screened $G$. $l u$ cidum for the production of mycelia biomass and bioactive metabolites.

G. lucidum was grown in a 250-ml flask con- taining $100 \mathrm{ml}$ seed culture medium at $28^{\circ} \mathrm{C}$ for $8 \mathrm{~d}$ with shaking at $180 \mathrm{r} / \mathrm{min}$, and was then inoculated at $10 \%(\mathrm{v} / \mathrm{v})$ into the fermentation culture at $28^{\circ} \mathrm{C}$ for $7 \mathrm{~d}$ with shaking at $180 \mathrm{r} / \mathrm{min}$. The seed culture medium contained $(\mathrm{g} / \mathrm{L})$ : potato extract 10 , glucose 20 , peptone $18, \mathrm{KH}_{2} \mathrm{PO}_{4} 3, \mathrm{MgSO}_{4} 1.5$, and vitamin $\mathrm{B}_{1}$ $\left(\mathrm{VB}_{1}\right) 0.05, \mathrm{pH}$ 5.5. The fermentation culture contained $(\mathrm{g} / \mathrm{L})$ : glucose 20, peptone $18, \mathrm{KH}_{2} \mathrm{PO}_{4} 3$, $\mathrm{MgSO}_{4}$ 1.5, and $\mathrm{VB}_{1}$ 0.05, $\mathrm{pH}$ 5.5.

\subsection{Preparation of the wort}

The wort was made from barley using the European Brewery Convention (EBC) official analysis method (Munck et al., 1989).

\subsection{Determination of mycelia biomass and intra- cellular triterpenoids (ITs)}

To determine mycelia biomass, mycelia were collected by centrifuging G. lucidum at $3000 \mathrm{r} / \mathrm{min}$ for $30 \mathrm{~min}$, washing three times in distilled water, and drying at $60{ }^{\circ} \mathrm{C}$ to a constant weight.

For the determination of ITs, mycelia were collected as above, mixed with $50 \times(1 \mathrm{~g} / 50 \mathrm{ml})$ of $95 \%$ ethanol and kept overnight, and then extracted twice by $400 \mathrm{~W}$ ultrasound at $75^{\circ} \mathrm{C}$ for $1 \mathrm{~h}$. The supernatant was merged and measured (Fang and Zhong, 2002b; Tang and Zhong, 2002; Xiao et al., 2006): $0.1 \mathrm{ml}$ of the sample diluent was heated in a test tube to dry solvent at $60{ }^{\circ} \mathrm{C}$ and then $0.2 \mathrm{ml} 0.05 \mathrm{~g} / \mathrm{ml}$ of vanillinglacial acetic acid solution and $0.5 \mathrm{ml}$ of perchloric acid were added and kept at $60^{\circ} \mathrm{C}$ for $20 \mathrm{~min}$; finally, $5 \mathrm{ml}$ of glacial acetic acid was added after cooling for $15 \mathrm{~min}$. The IT content was measured under $550 \mathrm{~nm}$ and IT production was expressed as follows: IT production $(\mathrm{mg} / 100 \mathrm{ml})=\mathrm{IT}$ content $(\mathrm{mg} / \mathrm{g}) \times$ mycelia biomass $(\mathrm{g} / 100 \mathrm{ml})$.

\subsection{Sample preparation of ganoderic acids}

The dried mycelia were pulverized, extracted three times with $40 \times(1 \mathrm{~g} / 40 \mathrm{ml})$ of $\mathrm{CHCl}_{3}$ in an ultrasonic water bath for $20 \mathrm{~min}$ (Zhang et al., 2006; Keypour et al., 2010), filtered, evaporated, and concentrated to about $1 / 5$ of its original volume at $50{ }^{\circ} \mathrm{C}$. The concentrated solution was then extracted with saturated aqueous $\mathrm{NaHCO}_{3}$, which was then acidified to $\mathrm{pH} 3-4$ with $6 \mathrm{~mol} / \mathrm{L} \mathrm{HCl}$ at $0{ }^{\circ} \mathrm{C}$. Finally, the insoluble precipitate obtained was dissolved in methanol and filtrated through a $0.45-\mu \mathrm{m}$ membrane filter unit prior to HPLC analysis (Guo et al., 2012). 


\subsection{HPLC instrumentation and chromatographic conditions}

HPLC analysis was performed on an Agilent series 1100 HPLC instrument (Agilent, Waldbroon, Germany) equipped with diode array detector (DAD) and an autosampler. The sample was separated on a ZORBAX SB-C18 column $(5 \mu \mathrm{m}, 4.6 \mathrm{~mm} \times 250 \mathrm{~mm}$; Agilent). The mobile phase consisted of methanol (A), $2 \%(0.2 \mathrm{~g} / \mathrm{ml})$ aqueous acetic acid (B), and acetonitrile (C). The column was eluted by a linear gradient which consisted of $30 \% \mathrm{~A}$ and $10 \%-30 \% \mathrm{C}$ in 0 $15 \mathrm{~min}, 30 \%-37 \% \mathrm{~A}$ and $30 \%-35 \% \mathrm{C}$ in $15-30 \mathrm{~min}$, $37 \%-38 \% \mathrm{~A}$ and $35 \%-39 \% \mathrm{C}$ in $30-60 \mathrm{~min}$, $38 \%-50 \% \mathrm{~A}$ and $39 \%-45 \% \mathrm{C}$ in $60-80 \mathrm{~min}$, and $50 \%$ $\mathrm{A}$ and $45 \%-50 \% \mathrm{C}$ in $80-100 \mathrm{~min}$. The flow rate was $0.2 \mathrm{ml} / \mathrm{min}$ at a column temperature of $35{ }^{\circ} \mathrm{C}$. The DAD was set up at $254 \mathrm{~nm}$ and 3D-plots were recorded between 200 and $400 \mathrm{~nm}$.

\subsection{LC-MS chromatographic conditions}

The mass spectra were acquired using the LCD Deca $x p$ max with an ESI source (ThermoFinnigan, San Jose, CA, USA), and were connected to the Agilent 1200 HPLC. The LC effluent was introduced into the ESI source at a post-column splitting ratio of $2: 1$. Ultrahigh-purity helium was used as the collision gas; high-purity nitrogen was used as the sheath and auxiliary gas. The ESI-MS spectra were acquired in the negative ion mode and the optimized parameters were as follows: ion spray voltage, $3 \mathrm{kV}$; sheath gas, 40 arbitrary units; auxiliary gas, 5 units; capillary temperature, $320{ }^{\circ} \mathrm{C}$; capillary voltage, $-4 \mathrm{~V}$; tube lens offset voltage, $-60 \mathrm{~V}$. For full scan MS analysis, the spectra were recorded in the range of $\mathrm{m} / \mathrm{z}$ $125-1500$. The collision energy was adjusted to $40 \%$ in LC-MS analysis.

\section{Results and discussion}

\subsection{Optimization of submerged fermentation conditions}

\subsubsection{Effects of the carbon source and its concentration}

Carbohydrates are the major nutrient for the growth and development of G. lucidum. Different carbon sources can have different effects on the catabolism of the cellular secondary metabolism. To select a suitable carbon source for mycelia growth and
IT production, five different carbon sources (glucose, $\mathrm{C} 1$; corn powder extract, $\mathrm{C} 2$; wort, $\mathrm{C} 3$; sucrose, $\mathrm{C} 4$; and soluble starch, C5) were added into the basal submerged culture individually at a level of $2 \%(\mathrm{w} / \mathrm{w})$. Mycelia biomass and IT production were used as screening indicators.

As shown in Fig. 1a, maximum mycelia biomass was obtained in glucose with a value of $1.38 \mathrm{~g} / 100 \mathrm{ml}$ and maximum IT production was in wort with a value of $49.62 \mathrm{mg} / 100 \mathrm{ml}$, while the mycelia biomass was $1.21 \mathrm{~g} / 100 \mathrm{ml}$.

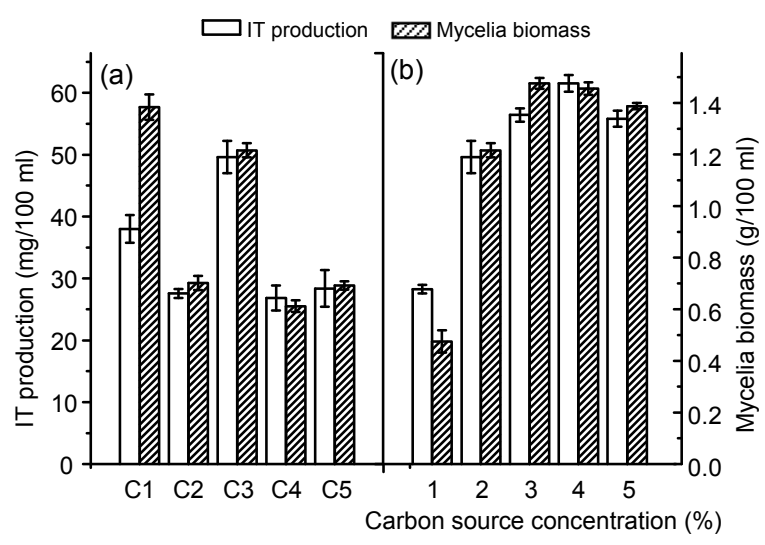

Fig. 1 Effects of initial carbon source (a) and the concentration of the suitable carbon source (b) on mycelia growth and intracellular triterpenoid (IT) production in shake flask culture of $\boldsymbol{G}$. lucidum

C1: glucose; C2: corn powder extract; C3: wort; C4: sucrose; C5: soluble starch. The results were expressed as the average of triple determination with \pm standard deviation (SD)

As the main raw material for brewing beer, dry barely has the following average chemical composition: total carbohydrate $(70 \%-85 \%)$, protein $(10.5 \%-$ $11.5 \%)$, inorganic material $(2 \%-4 \%)$, fat $(1.5 \%-2.0 \%)$, and other substances $(1.0 \%-2.0 \%)$. The carbohydrate contains starch $(50 \%-63 \%)$, sugar $(1.8 \%-2.0 \%)$, cellulose (5\%-6\%), and hemicellulose ( $\beta$-glucan $80 \%-90 \%$, pentosan $10 \%-20 \%)$. After saccharification treatment, about $75 \%-80 \%$ of the grist weight was converted into soluble products. Much more sugar (maltose, dextrins, glucose, etc.), soluble nitrogen, amino nitrogen, gums, and inorganic substances could be obtained, indicating that wort is more than a simple carbon source. As wort is low-cost, abundantly available, and conducive to the cultivation of microorganisms and industrial production, it is suitable for further study regarding mycelia growth and IT production. This is the first time that wort has been used 
as the sole carbon source for the growth of G. lucidum to increase IT production.

To find the most suitable concentration of wort for mycelia biomass and IT production, five different concentrations $(1 \%, 2 \%, 3 \%, 4 \%$, and $5 \%$ (i.e. 0.01 , $0.02,0.03,0.04$, and $0.05 \mathrm{~g} / \mathrm{ml})$ ) were separately added into the culture. From Fig. 1b, it can be seen that mycelia biomass and IT production increased with increasing concentration and reached maximum of $1.45 \mathrm{~g} / 100 \mathrm{ml}$ and $61.52 \mathrm{mg} / 100 \mathrm{ml}$, respectively, when wort concentration was $4 \%$. Mycelia biomass and IT production decreased to $1.38 \mathrm{~g} / 100 \mathrm{ml}$ and $55.80 \mathrm{mg} / 100 \mathrm{ml}$ when the concentration was $5 \%$, which would cause higher osmotic pressure. It was clear that $4 \%$ of wort was the optimum concentration.

\subsubsection{Effects of nitrogen source and its concentration}

Compared with inorganic nitrogen sources, organic nitrogen is more favorable for mycelia growth and the production of bioactive substances (Xiao et al., 2006). In this study, five different organic nitrogen sources including soybean meal (N1), bran (N2), peptone (N3), beef extract (N4), and yeast extract (N5) were added into the basal culture at a concentration of $1.8 \%(18 \mathrm{~g} / \mathrm{L})$. As shown in Fig. 2a, the maximum mycelia dry weight was $1.71 \mathrm{~g} / 100 \mathrm{ml}$ in soybean meal, while maximum IT production was $60.34 \mathrm{mg} / 100 \mathrm{ml}$ in yeast extract. Taking both biomass yield and IT production into consideration, yeast extract was chosen for fermentation of G. lucidum. In addition, mycelia biomass and IT production under $1.8 \%$ yeast extract were higher than those in previous reports (Fang and Zhong, 2002b; Xiao et al., 2006; Liu et al., 2012), mainly because of the large amounts of nitrogenous substances and other nutrients contained in yeast extract. To determine the most suitable concentration of yeast extract, five different levels $(0.8 \%, 1.3 \%$, $1.8 \%, 2.3 \%$, and $2.8 \%$ (i.e. $8,13,18,23$, and $28 \mathrm{~g} / \mathrm{L}$ )) were tested, as shown in Fig. 2b. IT production was maximal at $1.8 \%$, and biomass at $1.41 \mathrm{~g} / 100 \mathrm{ml}$ was maximal at $2.3 \%$. IT production at $2.3 \%$ was $55.70 \mathrm{mg} / 100 \mathrm{ml}$, a $7.7 \%$ decrease on production at $1.8 \%$. The results indicated that an excessive initial concentration was unfavourable to mycelia growth and IT biosynthesis because of the higher osmotic pressure caused by the higher nitrogen concentration (Mao et al., 2005). The yeast extract at $1.8 \%$ was chosen for the following research.

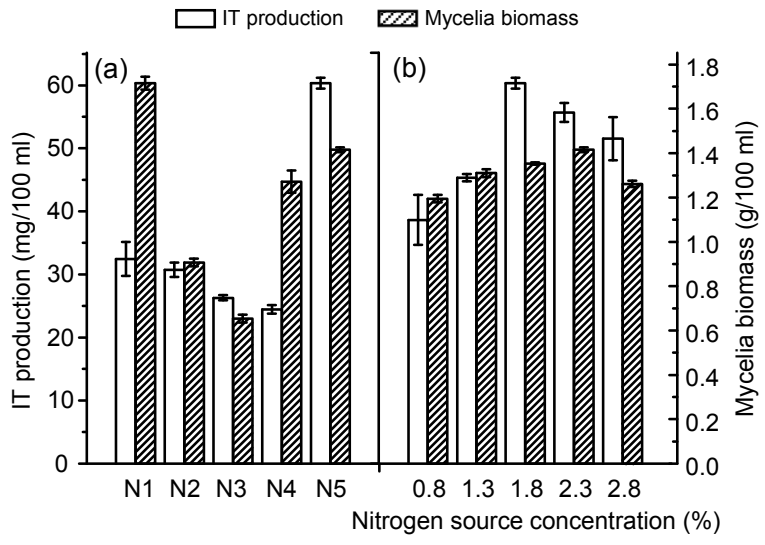

Fig. 2 Effects of initial nitrogen source (a) and the concentration of the suitable nitrogen source (b) on mycelia growth and intracellular triterpenoid (IT) production in shake flask culture of $\boldsymbol{G}$. lucidum

N1: soybean meal; N2: bran; N3: peptone; N4: beef extract; N5: yeast extract. The results were expressed as the average of triple determination with \pm standard deviation (SD)

\subsubsection{Effect of the initial $\mathrm{pH}$}

It was reported that $G$. lucidum prefers to grow in acidic conditions (Fang and Zhong, 2002a; Kim et al., 2006): the $\mathrm{pH}$ of the fermentation culture could affect fungal cell membrane function, cell morphology, and the availability of various nutrients. To determine the optimal $\mathrm{pH}$, G. lucidum was cultivated in basal culture at $\mathrm{pH}$ ranging from 3.5 to 7.5 (Fig. 3). The results showed that mycelia biomass and IT production reached a maximum at $\mathrm{pH} 5.5$, and declined rapidly outside the $\mathrm{pH}$ range of 4.5-6.5. Our results were consistent with submerged fermentation of $G$. lucidum in an acidic pH environment (Fang and Zhong, 2002a).

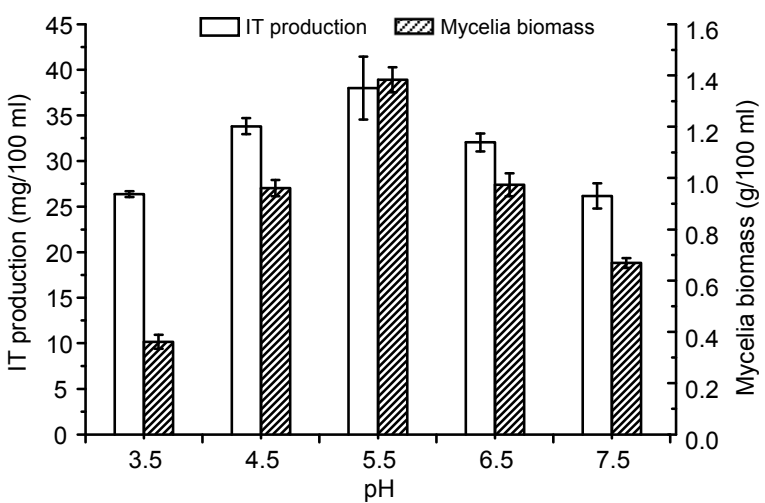

Fig. 3 Effect of initial $\mathrm{pH}$ on mycelia growth and intracellular triterpenoid (IT) production in shake flask culture of G. lucidum

The results were expressed as the average of triple determination with \pm standard deviation (SD) 
3.1.4 Response surface methodology (RSM) design and statistical analysis

RSM is an efficient statistical technique for optimization of multiple variables. A central composite design (CCD) was used for optimization of mycelia biomass and IT production by wort $(A)$, yeast extract $(B)$, and initial $\mathrm{pH}(C)$. The lowest and the highest levels of variables were: $3.5 \%$ and $4.5 \%$ of wort, $1.5 \%$ and $2.3 \%$ of yeast extract, $\mathrm{pH}$ at 5 and 6 , respectively. The CCD and the corresponding experimental results were shown in Table 1.

Regression analysis was performed to fit the response function $\left(R_{1}, R_{2}\right)$ for mycelia biomass. The $F$-test with a very low probability value $(P<0.01)$ indicated that the total model was statistically highly significant, while the lack of fit (0.076) was not significant. The $\mathrm{pH}$ had a positive linear effect on the response $R_{1}(P<0.05)$, while wort and yeast extract had no significant effect $(P>0.05)$. For IT production, the value of "Prob $>F$ " $(<0.001)$ showed that the model was highly significant, while the lack of fit (0.0619) was not significant. All three variables had significantly positive linear effects on the response $R_{2}$ $(P<0.01)$. The polynomial models for mycelia biomass yield $\left(Y_{1}\right)$ and IT production $\left(Y_{2}\right)$ were regressed by mainly considering the significant terms and were expressed by Eqs. (1) and (2):

$$
\begin{aligned}
Y_{1} & =1.85-0.011 A+0.0093 B-0.017 C+0.012 A B- \\
& 0.041 A C+0.017 B C-0.059 A^{2}-0.045 B^{2}-0.067 C^{2}, \\
Y_{2}= & 92.46+3.5 A+5.92 B-3.96 C+1.64 A B+0.2 A C- \\
& 1.49 B C-4.69 A^{2}-8.67 B^{2}-8.79 C^{2} .
\end{aligned}
$$

The effect on mycelia biomass and IT production of the interaction between any two variables while one variable was kept constant at its middle value was also analyzed. The contour and surface plots of the combined effect of wort and yeast extract on mycelia biomass showed that there was no significant interaction between the set of variables $(P>0.05)$ (Fig. 4). The biomass yield was significantly increased at increasing levels of wort and yeast extract,

\begin{tabular}{|c|c|c|c|c|c|}
\hline \multirow[b]{2}{*}{ Run } & \multicolumn{3}{|c|}{ Independent variables } & \multicolumn{2}{|c|}{ Response } \\
\hline & $\begin{array}{c}A \\
\text { Wort (\%) }\end{array}$ & $\begin{array}{c}B \\
\text { Yeast extract (\%) }\end{array}$ & $\begin{array}{c}\mathrm{C} \\
\mathrm{pH}\end{array}$ & $\begin{array}{l}\text { Mycelia biomass } \\
(\mathrm{g} / 100 \mathrm{ml})\end{array}$ & $\begin{array}{c}\text { IT production } \\
(\mathrm{mg} / 100 \mathrm{ml})\end{array}$ \\
\hline 1 & 3.50 & 2.1 & 5.00 & 1.59 & 75.07 \\
\hline 2 & 4.00 & 1.8 & 5.50 & 1.88 & 94.84 \\
\hline 3 & 3.50 & 1.5 & 6.00 & 1.69 & 56.36 \\
\hline 4 & 4.00 & 1.3 & 5.50 & 1.69 & 58.69 \\
\hline 5 & 4.00 & 1.8 & 5.50 & 1.89 & 93.20 \\
\hline 6 & 4.00 & 1.8 & 5.50 & 1.86 & 91.39 \\
\hline 7 & 3.16 & 1.8 & 5.50 & 1.77 & 73.95 \\
\hline 8 & 4.50 & 1.5 & 6.00 & 1.62 & 67.72 \\
\hline 9 & 4.00 & 1.8 & 5.50 & 1.80 & 89.79 \\
\hline 10 & 3.50 & 2.1 & 6.00 & 1.70 & 69.21 \\
\hline 11 & 4.50 & 2.1 & 5.00 & 1.73 & 92.16 \\
\hline 12 & 4.00 & 1.8 & 5.50 & 1.83 & 95.21 \\
\hline 13 & 4.00 & 1.8 & 5.50 & 1.84 & 90.78 \\
\hline 14 & 3.50 & 1.5 & 5.00 & 1.65 & 67.16 \\
\hline 15 & 4.50 & 2.1 & 6.00 & 1.67 & 76.23 \\
\hline 16 & 4.00 & 2.3 & 5.50 & 1.77 & 74.25 \\
\hline 17 & 4.00 & 1.8 & 4.66 & 1.72 & 72.79 \\
\hline 18 & 4.00 & 1.8 & 6.34 & 1.61 & 59.49 \\
\hline 19 & 4.84 & 1.8 & 5.50 & 1.61 & 81.52 \\
\hline 20 & 4.50 & 1.5 & 5.00 & 1.75 & 66.81 \\
\hline
\end{tabular}
but decreased when the variables' concentrations were excessive. Similarly, there was no significant

Table 1 Central composite design matrix and the responses of mycelia biomass and IT production 


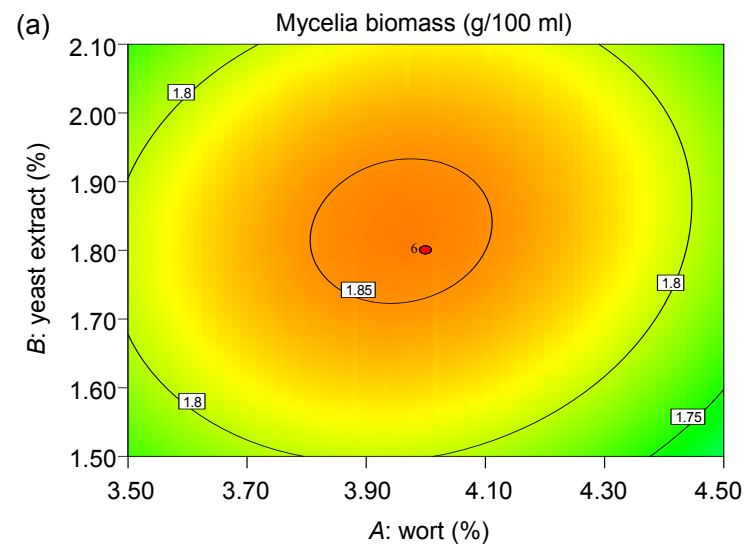

(c)

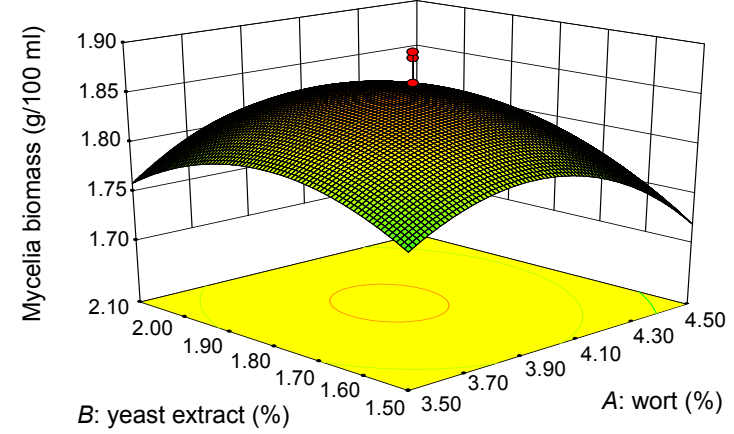

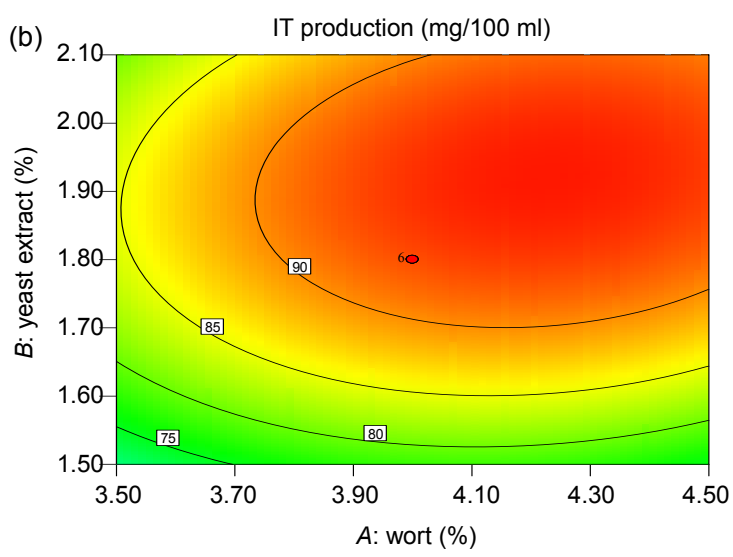

(d)

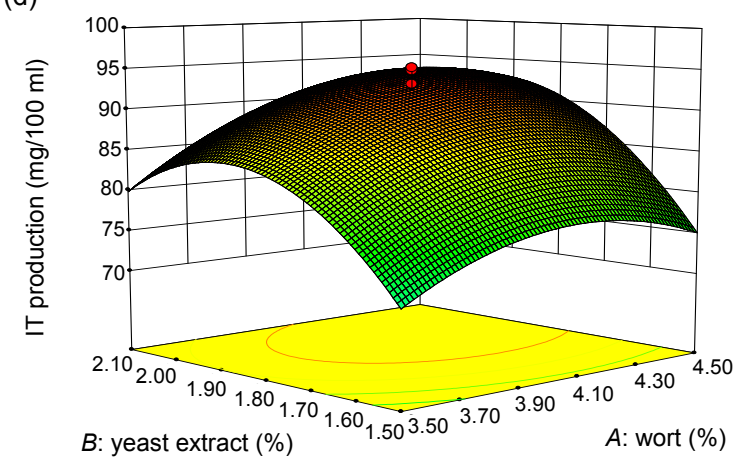

Fig. 4 Contour (a, b) and surface (c, d) plots of the combined effects of wort and yeast extract on the mycelia biomass (a, c) and IT production (b, d) (hold values: $\mathrm{pH}$ 5.5)

interaction between yeast extract and $\mathrm{pH}(P>0.05)$, while the interaction between wort and $\mathrm{pH}$ was just the opposite and significant $(P=0.0419)$. As shown in Fig. 4, IT production increased with increasing levels of wort and yeast extract, and dropped at excessive concentrations of variables. There was no significant interaction effect between wort and yeast extract on IT production $(P>0.05)$, as well as the interaction effects between any other two of three variables $(P>0.05)$. The model predicted that maximum mycelia biomass and IT production of $1.85 \mathrm{~g} / 100 \mathrm{ml}$ and $94.55 \mathrm{mg} / 100 \mathrm{ml}$, respectively, would appear at wort $4.10 \%$, yeast extract $1.89 \%$, and $\mathrm{pH} 5.40$.

Verification of the predicted optimum model and the existence of an optimum point for mycelia biomass and IT production was performed. The results of the triplicate experiments showed that the biomass and IT production could reach $1.87 \mathrm{~g} / 100 \mathrm{ml}$ and $93.21 \mathrm{mg} / 100 \mathrm{ml}$, respectively, which were in agreement with the predicted values, suggesting the model was valid for mycelia biomass and IT production.

\subsection{Identification of major compounds of triterpe- noids by HPLC-MS analysis}

G. lucidum was cultured using the optimal culture established above, and the triterpenoids were extracted for HPLC-MS analysis at negative mode which gave $[\mathrm{M}-\mathrm{H}]^{-}$and $[2 \mathrm{M}-\mathrm{H}]^{-}$ions. The dominant fragmentation pathways of the triterpenoids are losses of $\mathrm{H}_{2} \mathrm{O}$ and $\mathrm{CO}_{2}$, as well as fragment ions of $\mathrm{a}, \mathrm{b}, \mathrm{c}$ and $\mathrm{d}$ resulting from the cleavages of $\mathrm{C}$-ring and D-ring as shown in Fig. 5 (Yang et al., 2007). Molecular weight, HPLC retention time $\left(t_{\mathrm{R}}\right)$, and mass spectra were referred to literature data and an MS library. We tentatively identified and deduced the possible structure of 10 main constituents (Fig. 6 and Table 2) (Guo et al., 2012), most of them being ganoderic and lucidenic acids. 

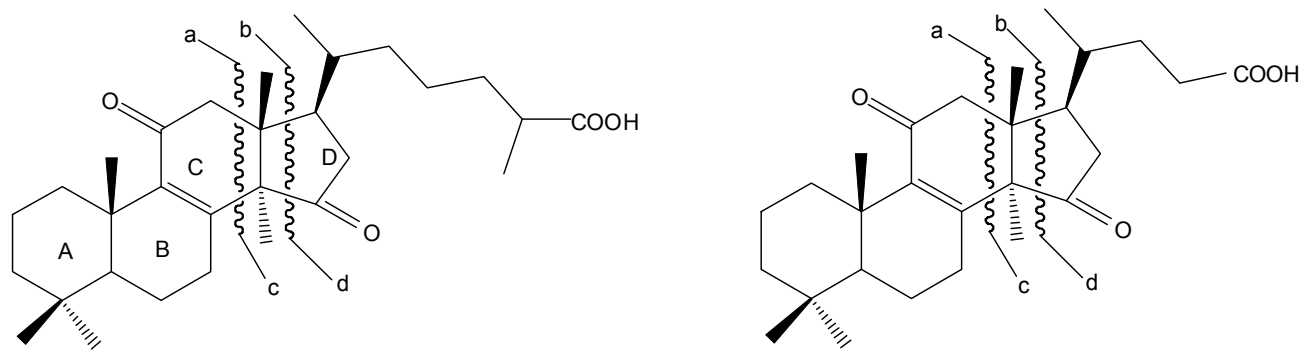

Fig. 5 Characteristic fragmentation of ganoderic acids

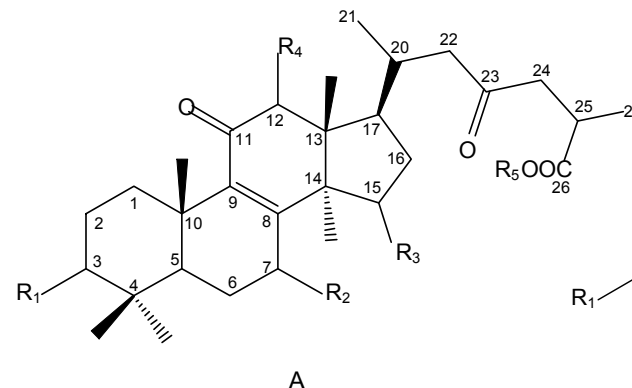

A

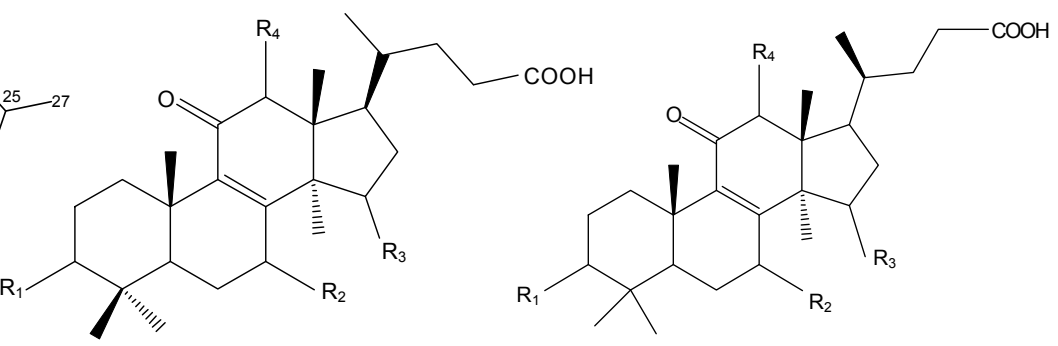

B

C

\begin{tabular}{|c|c|c|c|c|c|c|c|c|}
\hline No. & Compound name & Type & $\mathrm{R}_{1}$ & $\mathrm{R}_{2}$ & $\mathrm{R}_{3}$ & $\mathrm{R}_{4}$ & $\begin{array}{c}\text { Double } \\
\text { bond }\end{array}$ & $\begin{array}{c}\text { Molecular } \\
\text { weight }\end{array}$ \\
\hline 1 & Ganoderic acid A & $\mathrm{A}$ & $=\mathrm{O}$ & $\beta-\mathrm{OH}$ & $\alpha-\mathrm{OH}$ & $\mathrm{H}$ & & 516 \\
\hline 2 & Ganolucidic acid A & A & $=\mathrm{O}$ & $\mathrm{H}$ & $\alpha-\mathrm{OH}$ & $\mathrm{H}$ & & 500 \\
\hline 3 & Ganoderenic acid B & A & $\beta-\mathrm{OH}$ & $\beta-\mathrm{OH}$ & $=\mathrm{O}$ & $\mathrm{H}$ & $\Delta_{20,22}$ & 514 \\
\hline 4 & Elfvingic acid A & A & $=\mathrm{O}$ & $=\mathrm{O}$ & $\beta-\mathrm{OH}$ & $\alpha-\mathrm{OH}$ & $\Delta_{20,22}$ & 528 \\
\hline 5 & $\begin{array}{l}\text { 7,15-Dihydroxy-4,4,14-trimethyl-3,11- } \\
\text { dioxochol-8-en-24-oic acid }\end{array}$ & B & $=\mathrm{O}$ & $\mathrm{OH}$ & $\mathrm{OH}$ & $\mathrm{H}$ & & 460 \\
\hline 6 & $\begin{array}{l}\text { 3,7,15-Trihydroxy-4,4,14-trimethyl-11- } \\
\text { oxo-chol-8-en-24-oic acid }\end{array}$ & B & $\mathrm{OH}$ & $\mathrm{OH}$ & $\mathrm{OH}$ & $\mathrm{H}$ & & 462 \\
\hline 7 & $\begin{array}{l}\text { 3ß-Hydroxy-4,4,14-trimethyl-7,11,15- } \\
\text { trioxochol-8-en-24-oic acid }\end{array}$ & B & $\beta-\mathrm{OH}$ & $=\mathrm{O}$ & $=\mathrm{O}$ & $\mathrm{H}$ & & 458 \\
\hline 8 & Ganoderic acid F & A & $=\mathrm{O}$ & $=\mathrm{O}$ & $=\mathrm{O}$ & $\mathrm{H}$ & & 512 \\
\hline 9 & Lucidenic acid C & $\mathrm{C}$ & $\beta-\mathrm{OH}$ & $\beta-\mathrm{OH}$ & $=\mathrm{O}$ & $\beta-\mathrm{OH}$ & & 476 \\
\hline 10 & Ganoderic acid $\mathrm{H}$ & A & $\beta-\mathrm{OH}$ & $=\mathrm{O}$ & $=\mathrm{O}$ & $\beta$-OAc & & 572 \\
\hline
\end{tabular}

Fig. 6 Chemical structures of the triterpenoids identified from G. lucidum

\subsubsection{Identification of ganoderic acids of $\mathrm{C}_{30}$}

HPLC-ESI-MS spectra of Compound 1 showed $[\mathrm{M}-\mathrm{H}]^{-}$ion at $\mathrm{m} / \mathrm{z} 515\left(t_{\mathrm{R}}=33.90 \mathrm{~min}\right.$; Fig. 7$)$; it produced a prominent ion at $\mathrm{m} / \mathrm{z} 497.23$ by losing a molecule of $\mathrm{H}_{2} \mathrm{O}(\Delta m=18)$, and at $m / z 479.34,453.34$, 435.39 by further losing $\mathrm{H}_{2} \mathrm{O}$ and $\mathrm{CO}_{2}(\Delta m=44)$. $m / z 435.39$ underwent successive loss of $\mathrm{CH}_{3}(\Delta m=15)$ to generate an ion at $\mathrm{m} / \mathrm{z} 405.45$ and some minor signals at $m / z 301.27$ (b), 300.3 (b-1), 299.32 (b-2), and $285.36(\mathbf{b}-16)$; these ions were identified as the major fragments of ganoderic acid A. Similarly, Compound $\mathbf{8}$ was tentatively characterized as ganoderic acid F. 
Table 2 Identification of possible ganoderic acids from G. lucidum by HPLC-DAD-ESI-MS ${ }^{n}$ at 252 nm

\begin{tabular}{|c|c|c|c|c|}
\hline No. & $t_{\mathrm{R}}(\min )$ & Compound name & {$[\mathrm{M}-\mathrm{H}]^{-}, m / z$} & Fragmentation, $m / z$ \\
\hline 1 & 33.90 & $\begin{array}{l}\text { Ganoderic acid } \mathrm{A} \\
\left(\mathrm{C}_{30} \mathrm{H}_{44} \mathrm{O}_{7}\right)\end{array}$ & 515 & $\begin{array}{l}497.23,479.34,453.34,435.39,406.08, \\
405.45,301.27,300.30,299.32,285.36,195.19\end{array}$ \\
\hline 2 & 33.98 & $\begin{array}{l}\text { Ganolucidic acid A } \\
\left(\mathrm{C}_{30} \mathrm{H}_{44} \mathrm{O}_{6}\right)\end{array}$ & 499 & $481.18,455.19,437.09,287.70,285.12,201.40$ \\
\hline 3 & 34.69 & $\begin{array}{l}\text { Ganoderenic acid B } \\
\left(\mathrm{C}_{30} \mathrm{H}_{42} \mathrm{O}_{7}\right)\end{array}$ & 513 & $\begin{array}{l}495.23,480.86,451.37,437.40,424.10 \\
329.17,287.62\end{array}$ \\
\hline 4 & 40.60 & $\begin{array}{l}\text { Elfvingic acid A } \\
\left(\mathrm{C}_{30} \mathrm{H}_{40} \mathrm{O}_{8}\right)\end{array}$ & 527 & $507.50,506.80,480.74,478.22,465.20,435.51$ \\
\hline 5 & 45.31 & $\begin{array}{l}\text { 7,15-Dihydroxy-4,4,14-trimethyl-3,11- } \\
\text { dioxochol-8-en-24-oic acid } \\
\left(\mathrm{C}_{27} \mathrm{H}_{40} \mathrm{O}_{6}\right)\end{array}$ & 459 & $\begin{array}{l}440.95,422.86,415.04,397.08,307.10 \\
301.17,300.23,287.13,286.50\end{array}$ \\
\hline 6 & 50.74 & $\begin{array}{l}\text { 3,7,15-Trihydroxy-4,4,14-trimethyl-11- } \\
\text { oxo-chol-8-en-24-oic acid } \\
\left(\mathrm{C}_{27} \mathrm{H}_{42} \mathrm{O}_{6}\right)\end{array}$ & 461 & $\begin{array}{l}\text { 443.11, 424.82, 417.12, 398.57, 304.03, } \\
291.35,287.14\end{array}$ \\
\hline 7 & 58.22 & $\begin{array}{l}\text { 3 } \beta \text {-Hydroxy-4,4,14-trimethyl-7,11,15- } \\
\text { trioxochol-8-en-24-oic acid } \\
\left(\mathrm{C}_{27} \mathrm{H}_{38} \mathrm{O}_{6}\right)\end{array}$ & 457 & $\begin{array}{l}439.16,420.87,413.20,396.28,395.24, \\
394.54,385.65,384.79,379.38,341.32,285.37\end{array}$ \\
\hline 8 & 61.59 & $\begin{array}{l}\text { Ganoderic acid } \mathrm{F} \\
\left(\mathrm{C}_{30} \mathrm{H}_{40} \mathrm{O}_{7}\right)\end{array}$ & 511 & $493.12,449.12,438.18,434.23,321.16$ \\
\hline 9 & 67.17 & $\begin{array}{l}\text { Lucidenic acid } \mathrm{C} \\
\left(\mathrm{C}_{27} \mathrm{H}_{40} \mathrm{O}_{7}\right)\end{array}$ & 475 & $\begin{array}{l}457.03,443.11,439.24,431.11,429.12 \\
413.25,411.42,315.24\end{array}$ \\
\hline 10 & 82.40 & $\begin{array}{l}\text { Ganoderic acid } \mathrm{H} \\
\left(\mathrm{C}_{32} \mathrm{H}_{44} \mathrm{O}_{9}\right)\end{array}$ & 571 & $\begin{array}{l}553.21,509.33,508.68,468.23,462.19, \\
315.06,312.66,291.20\end{array}$ \\
\hline
\end{tabular}

$t_{\mathrm{R}}$ : retention time

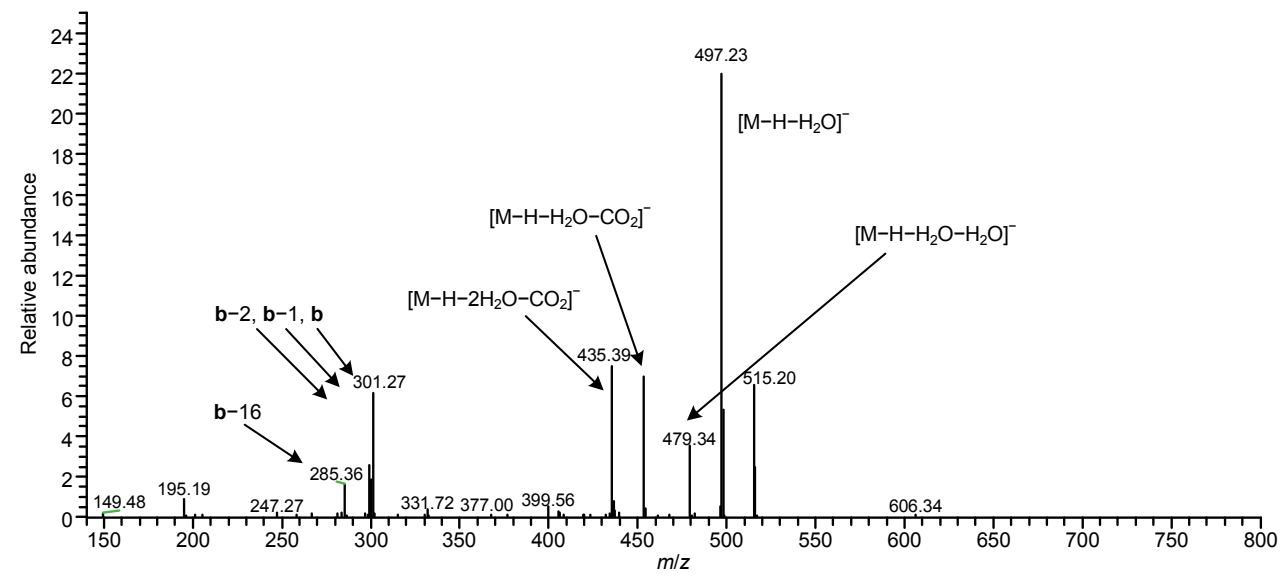

Fig. 7 Fragmentation ions of $\mathrm{MS}^{2}$ spectra for Compound 1

$\left[\mathrm{M}-\mathrm{H}-\mathrm{H}_{2} \mathrm{O}\right]^{-}$ion $\left(m / z\right.$ 497.23), $\left[\mathrm{M}-\mathrm{H}-\mathrm{H}_{2} \mathrm{O}-\mathrm{H}_{2} \mathrm{O}\right]^{-}$ion $\left(m / z\right.$ 479.34), $\left[\mathrm{M}-\mathrm{H}-\mathrm{H}_{2} \mathrm{O}-\mathrm{CO}_{2}\right]^{-}$ion $(m / z 453.34),\left[\mathrm{M}-\mathrm{H}-2 \mathrm{H}_{2} \mathrm{O}-\mathrm{CO}_{2}\right]^{-}$ ion $(\mathrm{m} / \mathrm{z} 435.39), \mathbf{b}(\mathrm{m} / \mathrm{z} 301.27), \mathbf{b}-1(\mathrm{~m} / \mathrm{z} 300.3), \mathbf{b}-2(\mathrm{~m} / \mathrm{z} 299.32), \mathbf{b}-16(\mathrm{~m} / \mathrm{z} 285.36)$

The $[\mathrm{M}-\mathrm{H}]^{-}$ion of Compound 2 was at $m / z 499$ $\left(t_{\mathrm{R}}=33.98 \mathrm{~min}\right)$; the base peaks in its MS spectrum were ions $(\mathrm{m} / \mathrm{z} 437.39)$, which appeared to be a dehydroxylated derivative of ganoderic acid $\mathrm{C}_{2}$. The characteristic fragment ions at $\mathrm{m} / \mathrm{z} 287.70$ and 285.12 were presumed to be $\mathbf{b}+2$ and $\mathbf{b}$, respectively, which indicated that D-ring was its major fragmentation pathway. Thus, Compound $\mathbf{2}$ was identified as probably ganolucidic acid $\mathrm{A}$ with a molecular structure of $\mathrm{C}_{30} \mathrm{H}_{44} \mathrm{O}_{6}$.
The $[\mathrm{M}-\mathrm{H}]^{-}$ion of Compound 3 was at $m / z 513$ $\left(t_{\mathrm{R}}=34.69 \mathrm{~min}\right)$. It gave $\left[\mathrm{M}-\mathrm{H}-\mathrm{H}_{2} \mathrm{O}\right]^{-}$ion $(\mathrm{m} / \mathrm{z}$ 495.23), which suggested that this character could be applied to all other ganoderenic acids, $\left[\mathrm{M}-\mathrm{H}-\mathrm{H}_{2} \mathrm{O}-\mathrm{CH}_{3}\right]^{-}$ion $(\mathrm{m} / \mathrm{z} 480.86)$, and $\left[\mathrm{M}-\mathrm{H}-\mathrm{H}_{2} \mathrm{O}-\mathrm{CO}_{2}\right]^{-}$ion $(\mathrm{m} / \mathrm{z} 451.37)$. On account of the different side chains on $\mathrm{C}-17$, it possessed characteristic ions at $m / z 329.17(\mathbf{e}-2 \mathrm{H})$ and $m / z 287.62\left(\mathbf{b}-\mathrm{H}-\mathrm{CH}_{3}\right)$. Compound 3 was identified as probably ganoderenic acid B (Yang et al., 2007). 
The peak at 40.60 min (Compound 4) showed the characteristics of $[\mathrm{M}-\mathrm{H}]^{-}$ion $(\mathrm{m} / \mathrm{z} 527.00)$ and $\left[\mathrm{M}-2 \mathrm{H}-\mathrm{H}_{2} \mathrm{O}\right]^{-}$ion $(\mathrm{m} / \mathrm{z} 507.50,506.80)$, which indicated that one carbonyl was hydrogenized. The ion $m / z$ 507.50, 506.80 continuously eliminated $\mathrm{CH}_{2}$ $(\Delta m=14), \mathrm{CH}_{3}(\Delta m=15)$, and $\mathrm{CO}_{2}$ to become $\mathrm{m} / \mathrm{z}$ 480.74, 478.22, and 465.20, and Compound 4 was temporarily identified as elfvingic acid $\mathrm{A}$ with a molecular structure of $\mathrm{C}_{30} \mathrm{H}_{40} \mathrm{O}_{8}$.

\subsubsection{Identification of ganoderic acids of $\mathrm{C}_{27}$}

Lucidenic acid is a type of compound which has a skeleton of lanostane containing 27 carbon atoms and is different from ganoderic acid in its side chain. Compound $5\left(t_{\mathrm{R}}=45.31 \mathrm{~min}\right)$ gave the $[\mathrm{M}-\mathrm{H}]^{-}$ion at $\mathrm{m} / \mathrm{z} 459.00$ and it produced the prominent ions of $\mathrm{m} / \mathrm{z}$ $440.95,422.86$, and 415.04 by consecutively losing $\mathrm{H}_{2} \mathrm{O}$ and $\mathrm{CO}_{2}$. Its $\mathrm{MS}^{2}$ spectra gave a list of ions at $\mathrm{m} / \mathrm{z}$ 301.17 (b), $300.23(\mathbf{b}-1), 287.13\left(\mathbf{b}-\mathrm{CH}_{2}\right)$, and 286.50 $\left(\mathbf{b}-\mathrm{CH}_{3}\right)$, which indicated that there are hydroxyls attached at $\mathrm{C}_{17}$ and $\mathrm{C}_{15}$ and that Compound 5 possesses 27 carbon atoms and belongs to the lucidenic acids. In summary, Compound $\mathbf{5}$ was tentatively identified as 7,15-dihydroxy-4,4,14-trimethyl-3,11dioxochol-8-en-24-oic acid, which was first reported by Yang et al. (2007).

The fragmentation behavior of Compound $\mathbf{6}$ in $\mathrm{HPLC}^{-\mathrm{MS}^{n}}$ spectra gave the $[\mathrm{M}-\mathrm{H}]^{-}$ion at $\mathrm{m} / \mathrm{z} 461.00$ $\left(t_{\mathrm{R}}=50.74 \mathrm{~min}\right)$ (Fig. 8), and the base peaks included $\left[\mathrm{M}-\mathrm{H}-\mathrm{H}_{2} \mathrm{O}\right]^{-}$ion $\left(\mathrm{m} / \mathrm{z}\right.$ 443.11) and $\left[\mathrm{M}-\mathrm{H}-\mathrm{H}_{2} \mathrm{O}-\right.$ $\left.\mathrm{H}_{2} \mathrm{O}\right]^{-}$ion $(\mathrm{m} / \mathrm{z} 424.82)$, which are prominent ions in the fragmentation of lucidenic acids. It also gave $\left[\mathrm{M}-\mathrm{H}-\mathrm{CO}_{2}\right]^{-}(\mathrm{m} / \mathrm{z} 417.12)$ and $\left[\mathrm{M}-2 \mathrm{H}-\mathrm{CH}_{3} \mathrm{COOH}\right]^{-}$ $(\mathrm{m} / \mathrm{z}$ 398.57), which showed that a molecule of acetic acid $(\Delta m=60)$ was lost through the $\beta$-cleavage of the carboxy group. Minor signals at $m / z 304.03(\mathbf{b}-1)$, $m / z 291.35\left(\mathbf{b}-\mathrm{CH}_{2}\right)$ and $m / z 287.14\left(\mathbf{b}-\mathrm{CH}_{2}-\mathrm{CH}_{2}\right)$ were also present and Compound $\mathbf{6}$ was provisionally identified as 3,7,15-trihydroxy-4,4,14-trimethyl-11oxo-chol-8-en-24-oic acid (Guo et al., 2012).

The $[\mathrm{M}-\mathrm{H}]^{-}$ion of Compound 7 was at $m / z 457.00$ $\left(t_{\mathrm{R}}=58.22 \mathrm{~min}\right.$ ) (Fig. 9) with the following base peaks: $\left[\mathrm{M}-\mathrm{H}-\mathrm{H}_{2} \mathrm{O}\right]^{-}\left(\mathrm{m} / \mathrm{z}\right.$ 439.16), which eliminated $\mathrm{H}_{2} \mathrm{O}$, $\mathrm{CO}_{2}$, and $\mathrm{CH}_{3} \mathrm{COOH}$ consecutively to $\mathrm{m} / \mathrm{z} 420.87$, 413.20, 396.28, 395.24, and $285.37\left(\mathbf{b}-1-\mathrm{CH}_{3}\right)$, which was identified as probably $3 \beta$-hydroxy-4,4,14-trimethyl7,11,15-trioxochol-8-en-24-oic acid. Using a similar analysis method, Compound 9 was temporarily identified as lucidenic acid C (Nishitoba et al., 1984).

\subsubsection{Identification of ganoderic acid $\mathrm{H}\left(\mathrm{C}_{32}\right)$}

The $[\mathrm{M}-\mathrm{H}]^{-}$ion of Compound $\mathbf{1 0}$ was at $\mathrm{m} / \mathrm{z}$ $571.00\left(t_{\mathrm{R}}=82.40 \mathrm{~min}\right)$ (Fig. 10), which showed the $\left[\mathrm{M}-\mathrm{H}-\mathrm{H}_{2} \mathrm{O}\right]^{-}$at $m / z$ 553.21, $\left[\mathrm{M}-\mathrm{H}-\mathrm{H}_{2} \mathrm{O}-\mathrm{CO}_{2}\right]^{-}$at $\mathrm{m} / \mathrm{z}$ 508.68, and $\left[\mathrm{M}-\mathrm{H}-2 \mathrm{H}_{2} \mathrm{O}-\mathrm{CO}_{2}-\mathrm{CO}\right]^{-}$at $\mathrm{m} / z$ 462.19. The resulting $\mathrm{m} / z 467.00$ ion then gave ions at $\mathrm{m} / \mathrm{z} 315.00(\mathbf{b}-2)$ and $291.20(\mathbf{b}+2-\mathrm{CO})$. Thus, it was temporarily identified as ganoderic acid $\mathrm{H}$, which showed that the $\mathrm{C}_{12}$ was acetylated.

To sum up, the structures of ganoderic acids preliminarily identified by HPLC-ESI-MS ${ }^{2}$ were shown in Fig. 11.

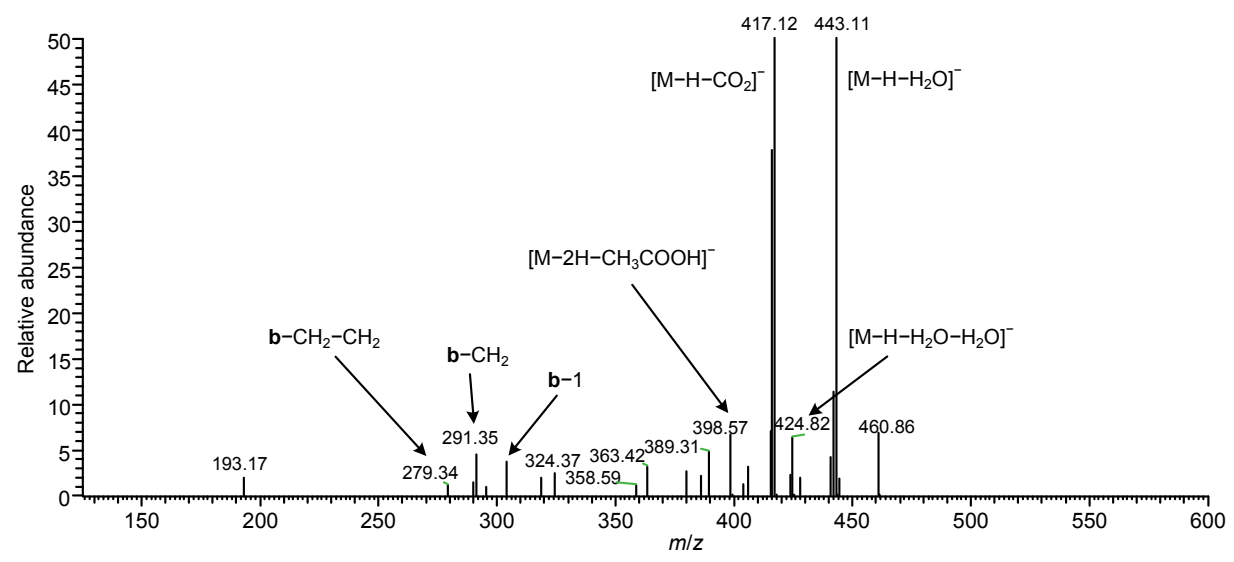

Fig. 8 Fragmentation ions of $\mathrm{MS}^{2}$ spectra for Compound 6

$\left[\mathrm{M}-\mathrm{H}-\mathrm{H}_{2} \mathrm{O}\right]^{-}$ion $(\mathrm{m} / \mathrm{z} 443.11),\left[\mathrm{M}-\mathrm{H}-\mathrm{H}_{2} \mathrm{O}-\mathrm{H}_{2} \mathrm{O}\right]^{-}$ion $\left(\mathrm{m} / z\right.$ 424.82), $\left[\mathrm{M}-\mathrm{H}-\mathrm{CO}_{2}\right]^{-}$ion $(\mathrm{m} / \mathrm{z} 417.12),\left[\mathrm{M}-2 \mathrm{H}-\mathrm{CH}_{3} \mathrm{COOH}\right]^{-}$ ion $\left(m / z\right.$ 398.57), b-1 (m/z 304.03), b- $\mathrm{CH}_{2}\left(\mathrm{~m} / z\right.$ 291.35), $\mathbf{b}-\mathrm{CH}_{2}-\mathrm{CH}_{2}(\mathrm{~m} / \mathrm{z} 287.14)$ 


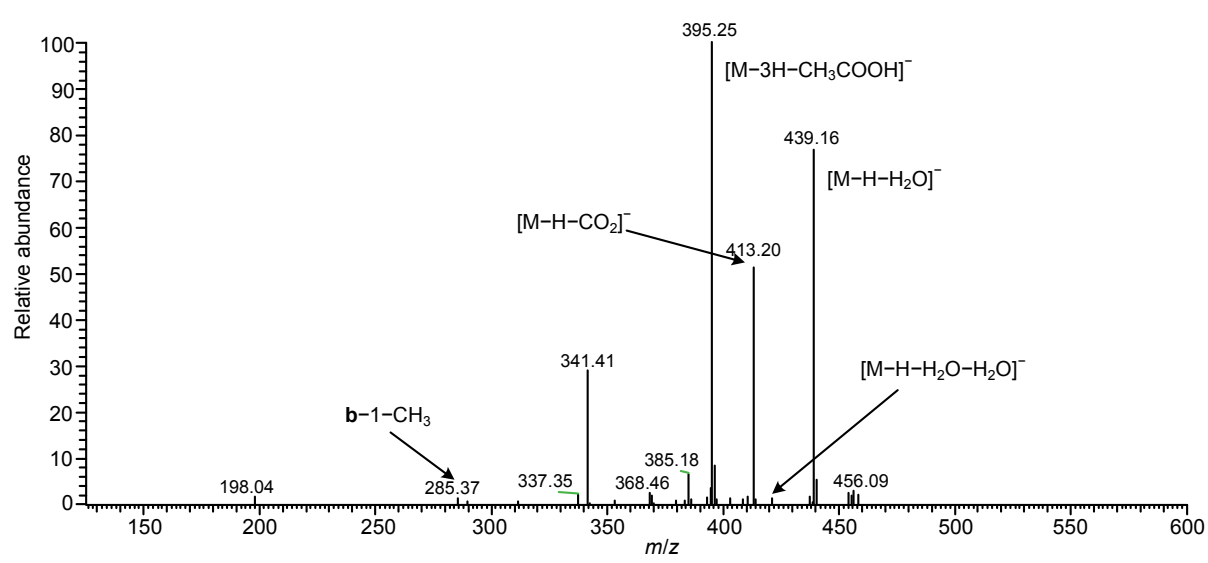

Fig. 9 Fragmentation ions of $\mathrm{MS}^{2}$ spectra for Compound 7

$\left[\mathrm{M}-\mathrm{H}-\mathrm{H}_{2} \mathrm{O}\right]^{-}$ion $(\mathrm{m} / \mathrm{z} 439.16),\left[\mathrm{M}-\mathrm{H}-\mathrm{H}_{2} \mathrm{O}-\mathrm{H}_{2} \mathrm{O}\right]^{-}$ion $(\mathrm{m} / \mathrm{z} 420.87),\left[\mathrm{M}-\mathrm{H}-\mathrm{CO}_{2}\right]^{-}$ion $(\mathrm{m} / \mathrm{z} 413.20),\left[\mathrm{M}-3 \mathrm{H}-\mathrm{CH}_{3} \mathrm{COOH}\right]$ ion $(\mathrm{m} / \mathrm{z} 395.24), \mathbf{b}-1-\mathrm{CH}_{3}(\mathrm{~m} / \mathrm{z} 285.37)$

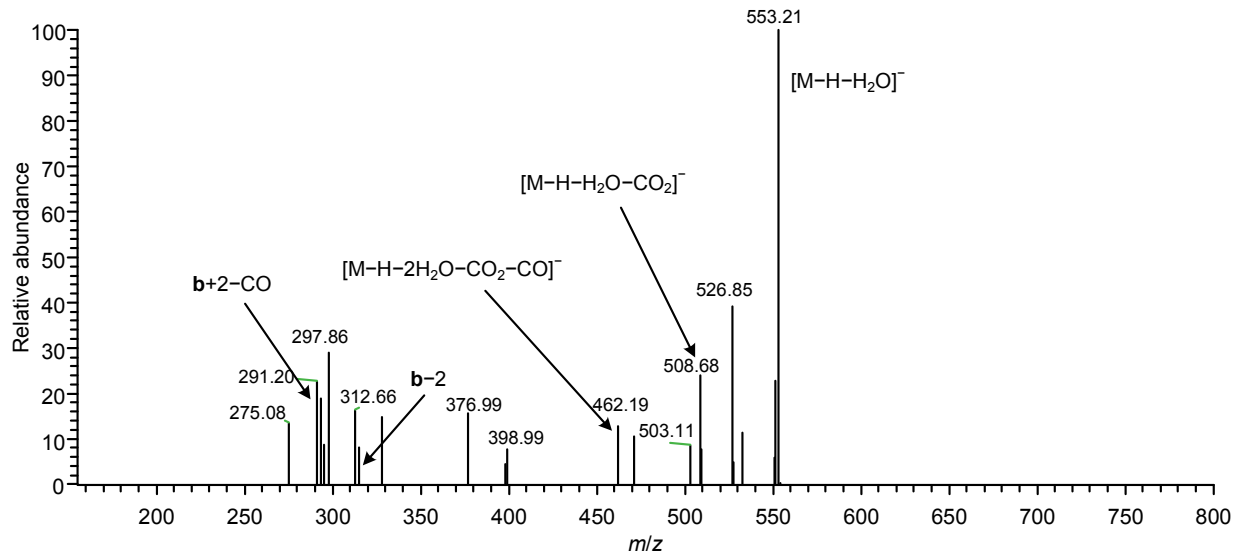

Fig. 10 Fragmentation ions of $\mathrm{MS}^{2}$ spectra for Compound 10

$\left[\mathrm{M}-\mathrm{H}-\mathrm{H}_{2} \mathrm{O}\right]^{-}$ion $(\mathrm{m} / \mathrm{z} 553.21),\left[\mathrm{M}-\mathrm{H}-\mathrm{H}_{2} \mathrm{O}-\mathrm{CO}_{2}\right]^{-}$ion $(\mathrm{m} / \mathrm{z} 508.68),\left[\mathrm{M}-\mathrm{H}-2 \mathrm{H}_{2} \mathrm{O}-\mathrm{CO}_{2}-\mathrm{CO}\right]^{-}$ion $(\mathrm{m} / \mathrm{z} 462.19), \mathbf{b}-2(\mathrm{~m} / \mathrm{z}$ $315.00), \mathbf{b}+2-\mathrm{CO}(\mathrm{m} / \mathrm{z} 291.20)$

\section{Conclusions}

G. lucidum has received considerable attention for its wide application as a medicinal ingredient. Submerged fermentation of G. lucidum was optimized by RSM, with a mycelia biomass and IT production of $1.87 \mathrm{~g} / 100 \mathrm{ml}$ and $93.21 \mathrm{mg} / 100 \mathrm{ml}$, respectively, using wort $4.10 \%$, yeast extract $1.89 \%$, and $\mathrm{pH} 5.40$. Previous studies have established glucose as an important carbohydrate source (Xu et al., 2008; Liu et al., 2010). For the first time, we determined wort as the best carbon source to increase IT production. Wort is low-cost, abundant, and conducive to microorganism cultivation.
The HPLC-ESI-MS approach was demonstrated successfully in the screening of complex triterpenoid mixtures and the specific identification of ganoderic acids. This is a worthwhile tool to help rapid semi-preparative purification of targeted ganoderic acids (Cheng et al., 2011). In this study, 10 possible ganoderic acids were identified from the triterpenoid extract using HPLC-MS ${ }^{n}$ with the elimination of $\mathrm{H}_{2} \mathrm{O}$ and $\mathrm{CO}_{2}$. Further study is needed to purify individual compounds from the extract using column chromatography and to understand their possible biological functions against various types of disease. 


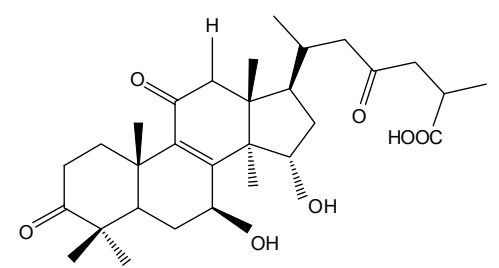

Compound 1

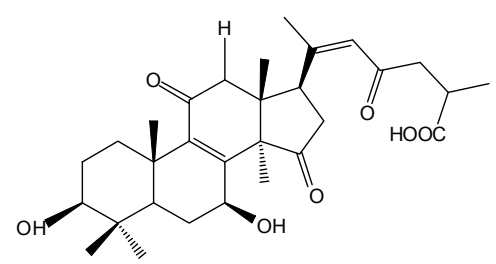

Compound 3

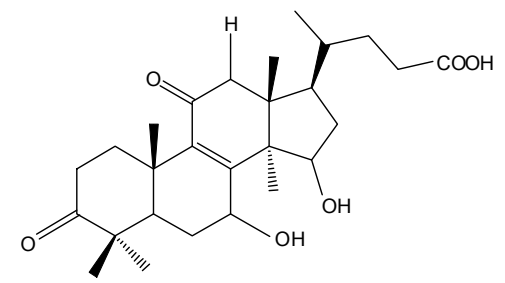

Compound 5

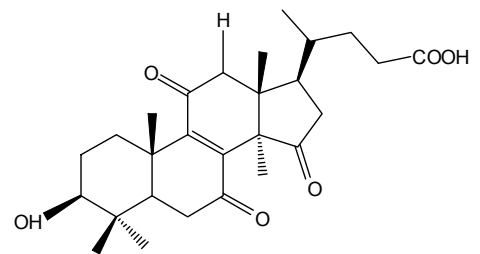

Compound 7

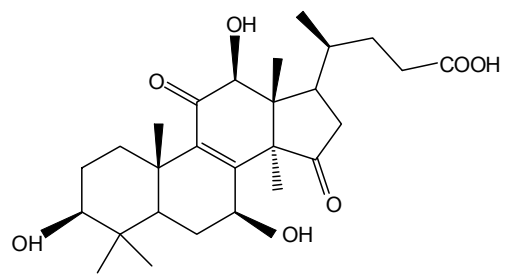

Compound 9

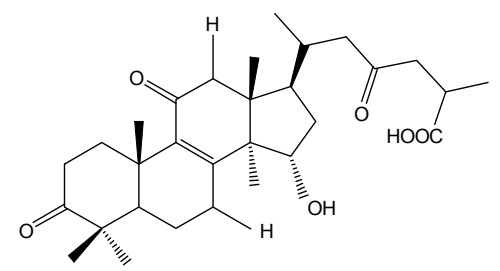

Compound 2

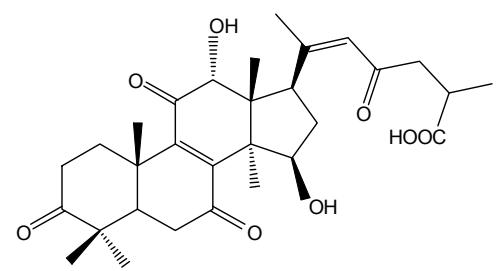

Compound 4

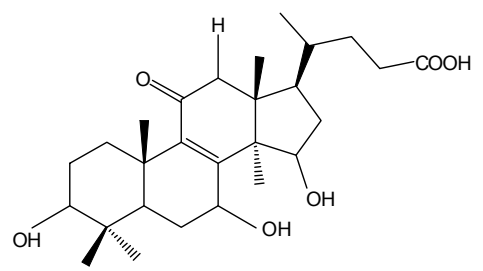

Compound 6

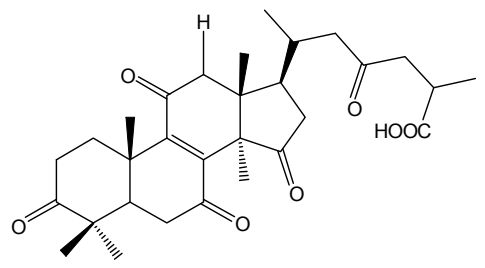

Compound 8

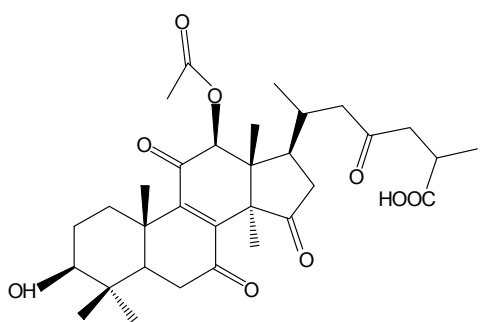

Compound 10

Fig. 11 Structures of 10 ganoderic acids preliminarily identified by HPLC-ESI-MS ${ }^{2}$ 


\section{Compliance with ethics guidelines}

Mei-lin CUI, Huan-yi YANG, and Guo-qing HE declare that they have no conflict of interest.

This article does not contain any studies with human or animal subjects performed by any of the authors.

\section{References}

Cheng, C.R., Yang, M., Wu, Z.Y., et al., 2011. Fragmentation pathways of oxygenated tetracyclic triterpenoids and their application in the qualitative analysis of Ganoderma lucidum by multistage tandem mass spectrometry. Rapid Commun. Mass Spectrom., 25(9):1323-1335. [doi:10. 1002/rcm.4989]

Ding, N., Yang, Q., Huang, S.S., et al., 2010. Separation and determination of four ganoderic acids from dried fermentation mycelia powder of Ganoderma lucidum by capillary zone electrophoresis. J. Pharm. Biomed. Anal., 53(5):1224-1230. [doi:10.1016/j.jpba.2010.07.025]

Fang, Q.H., Zhong, J.J., 2002a. Effect of initial pH on production of ganoderic acid and polysaccharide by submerged fermentation of Ganoderma lucidum. Process Biochem., 37(7):769-774. [doi:10.1016/S0032-9592(01) 00278-3]

Fang, Q.H., Zhong, J.J., 2002b. Submerged fermentation of higher fungus Ganoderma lucidum for production of valuable bioactive metabolites-ganoderic acid and polysaccharide. Biochem. Eng. J., 10(1):61-65. [doi:10.1016/ S1369-703X(01)00158-9]

Fang, Q.H., Tang, Y.J., Zhong, J.J., 2002. Significance of inoculation density control in production of polysaccharide and ganoderic acid by submerged culture of Ganoderma lucidum. Process Biochem., 37(12):13751379. [doi:10.1016/S0032-9592(02)00017-1]

Guo, X.Y., Han, J., Ye, M., et al., 2012. Identification of major compounds in rat bile after oral administration of total triterpenoids of Ganoderma lucidum by high-performance liquid chromatography with electrospray ionization tandem mass spectrometry. J. Pharm. Biomed. Anal., 63: 29-39. [doi:10.1016/j.jpba.2012.01.030]

Guo, X.Y., Liu, D., Ye, M., et al., 2013. Structural characterization of minor metabolites and pharmacokinetics of ganoderic acid C2 in rat plasma by HPLC coupled with electrospray ionization tandem mass spectrometry. $J$. Pharm. Biomed. Anal., 75:64-73. [doi:10.1016/j.jpba. 2012.11.024]

Keypour, S., Rafati, H., Riahi, H., et al., 2010. Qualitative analysis of ganoderic acids in Ganoderma lucidum from Iran and China by RP-HPLC and electrospray ionisationmass spectrometry (ESI-MS). Food Chem., 119(4): 1704-1708. [doi:10.1016/j.foodchem.2009.09.058]

Kim, H.H., Na, J.G., Chang, Y.K., et al., 2004. Optimization of submerged culture conditions for mycelial growth and exopolysaccharides production by Agaricus blazei. J. Microbiol. Biotechnol., 14(5):944-951.

Kim, H.M., Paik, S.Y., Ra, K.S., et al., 2006. Enhanced production of exopolysaccharides by fed-batch culture of
Ganoderma resinaceum DG-6556. J. Microbiol., 44(2): 233-242.

Lin, J.H., Yang, S.S., 2006. Mycelium and polysaccharide production of Agaricus blazei Murrill by submerged fermentation. J. Microbiol., Immunol. Infect., 39(2): 98-108.

Liu, G.Q., Zhang, K.C., 2005. Mechanisms of the anticancer action of Ganoderma lucidum (Leyss. ex Fr.) Karst.: a new understanding. J. Integr. Plant Biol., 47(2):129-135. [doi:10.1111/j.1744-7909.2005.00037.x]

Liu, G.Q., Lin, Q.L., Ren, G.P., et al., 2010. Use of response surface methodology to optimize critical medium components for biomass and extracellular polysaccharide production by Ganoderma sinense. Afr. J. Microbiol. Res., 4(24):2735-2741.

Liu, G.Q., Wang, X.L., Han, W.J., et al., 2012. Improving the fermentation production of the individual key triterpene ganoderic acid me by the medicinal fungus Ganoderma lucidum in submerged culture. Molecules, 17(11): 12575-12586. [doi:10.3390/molecules 171112575]

Liu, R.M., Zhong, J.J., 2011. Ganoderic acid Mf and S induce mitochondria mediated apoptosis in human cervical carcinoma HeLa cells. Phytomedicine, 18(5):349-355. [doi:10.1016/j.phymed.2010.08.019]

Ma, K., Ren, J., Han, J., et al., 2014. Ganoboninketals A-C, antiplasmodial 3,4-seco-27-norlanostane triterpenes from Ganoderma boninense Pat. J. Nat. Prod., 77(8):18471852. [doi:10.1021/np5002863]

Mao, X.B., Eksriwong, T., Chauvatcharin, S., et al., 2005. Optimization of carbon source and carbon/nitrogen ratio for cordycepin production by submerged cultivation of medicinal mushroom Cordyceps militaris. Process Biochem., 40(5):1667-1672. [doi:10.1016/j.procbio.2004.06.046]

Min, B.S., Nakamura, N., Miyashiro, H., et al., 1998. Triterpenes from the spores of Ganoderma lucidum and their inhibitory activity against HIV-1 protease. Chem. Pharm. Bull., 46(10):1607-1612. [doi:10.1248/cpb.46.1607]

Munck, L., Jorgensen, K.G., Ruud-Hansen, J., et al., 1989. The EBC methods for determination of high molecular weight $\beta$-glucan in barley, malt, wort and beer. J. I. Brewing, 95(2):79-82. [doi:10.1002/j.2050-0416.1989.tb04612.x]

Nishitoba, T., Sato, H., Kasai, T., et al., 1984. New bitter $\mathrm{C}_{27}$ and $\mathrm{C}_{30}$ terpenoids from the fungus Ganoderma lucidum (Reishi). Agric. Biol. Chem., 48(11):2905-2907. [doi:10. 1271/bbb1961.48.2905]

Paterson, R.R.M., 2006. Ganoderma-a therapeutic fungal biofactory. Phytochemistry, 67(18):1985-2001. [doi:10. 1016/j.phytochem.2006.07.004]

Qiao, Y., Zhang, X.M., Qiu, M.H., 2007. Two novel lanostane triterpenoids from Ganoderma sinense. Molecules, 12(8): 2038-2046. [doi:10.3390/12082038]

Shiao, M.S., 2003. Natural products of the medicinal fungus Ganoderma lucidum: occurrence, biological activities, and pharmacological functions. Chem. Rec., 3(3):172-180. [doi:10.1002/tcr.10058]

Tang, W., Liu, J.W., Zhao, W.M., et al., 2006. Ganoderic acid 
$\mathrm{T}$ from Ganoderma lucidum mycelia induces mitochondria mediated apoptosis in lung cancer cells. Life Sci., 80(3):205-211. [doi:10.1016/j.lfs.2006.09.001]

Tang, Y.J., Zhong, J.J., 2002. Fed-batch fermentation of Ganoderma lucidum for hyperproduction of polysaccharide and ganoderic acid. Enzyme Microb. Technol., 31(1): 20-28. [doi:10.1016/S0141-0229(02)00066-2]

Tang, Y.J., Zhong, J.J., 2004. Modeling the kinetics of cell growth and ganoderic acid production in liquid static cultures of the medicinal mushroom Ganoderma lucidum. Biochem. Eng. J., 21(3):259-264. [doi:10.1016/j.bej.2004 06.008]

Tang, Y.J., Zhang, W., Zhong, J.J., 2009. Performance analyses of a pH-shift and DOT-shift integrated fed-batch fermentation process for the production of ganoderic acid and Ganoderma polysaccharides by medicinal mushroom Ganoderma lucidum. Bioresource Technol., 100(5):18521859. [doi:10.1016/j.biortech.2008.10.005]

Thyagarajan, A., Jedinak, A., Nguyen, H., et al., 2010. Triterpenes from Ganoderma Lucidum induce autophagy in colon cancer through the inhibition of p38 mitogenactivated kinase (p38 MAPK). Nutr. Cancer, 62(5): 630-640. [doi:10.1080/01635580903532390]

Wagner, R., Mitchell, D.A., Lanzi Sassaki, G., et al., 2003. Current techniques for the cultivation of Ganoderma lucidum for the production of biomass, ganoderic acid and polysaccharides. Food Technol. Biotechnol., 41(4):371-382.

Wagner, R., Mitchell, D.A., Sassaki, G.L., et al., 2004. Links between morphology and physiology of Ganoderma lucidum in submerged culture for the production of exopolysaccharide. J. Biotechnol., 114(1):153-164. [doi:10. 1016/j.jbiotec.2004.06.013]

Wasser, S.P., 2010. Medicinal mushroom science: history, current status, future trends, and unsolved problems. Int. J. Med. Mushrooms, 12(1):1-16. [doi:10.1615/IntJMedMushr. v12.i1.10]

Wu, G.S., Lu, J.J., Guo, J.J., et al., 2012. Ganoderic acid DM, a natural triterpenoid, induces DNA damage, G1 cell cycle arrest and apoptosis in human breast cancer cells. Fitoterapia, 83(2):408-414. [doi:10.1016/j.fitote.2011. 12.004]

Xiao, J.H., Chen, D.X., Wan, W.H., et al., 2006. Enhanced simultaneous production of mycelia and intracellular polysaccharide in submerged cultivation of Cordyceps jiangxiensis using desirability functions. Process Biochem., 41(8):1887-1893. [doi:10.1016/j.procbio.2006.03.031]

Xu, J.W., Zhao, W., Zhong, J.J., 2010. Biotechnological production and application of ganoderic acids. Appl. Microbiol. Biotechnol., 87(2):457-466. [doi:10.1007/ s00253-010-2576-5]

Xu, P., Ding, Z.Y., Qian, Z., et al., 2008. Improved production of mycelial biomass and ganoderic acid by submerged culture of Ganoderma lucidum SB97 using complex media. Enzy. Microb. Technol., 42(4):325-331. [doi:10.1016/ j.enzmictec.2007.10.016]
Yang, M., Wang, X., Guan, S., et al., 2007. Analysis of triterpenoids in Ganoderma lucidum using liquid chromatography coupled with electrospray ionization mass spectrometry. J. Am. Soc. Mass Spectrom., 18(5):927-939. [doi:10.1016/j.jasms.2007.01.012]

Zhang, J., Zhang, L., Duan, J., et al., 2006. On-line hyphenation of supercritical fluid extraction and two-dimensional high performance liquid chromatography-atmospheric pressure chemical ionization tandem mass spectrometer for the analysis of Ganoderma lucidum. J. Sep. Sci., 29(16):2514-2522. [doi:10.1002/jssc.200600217]

Zhang, W.X., Zhong, J.J., 2010. Effect of oxygen concentration in gas phase on sporulation and individual ganoderic acids accumulation in liquid static culture of Ganoderma lucidum. J. Biosci. Bioeng., 109(1):37-40. [doi:10.1016/ j.jbiosc.2009.06.024]

Zhao, W., Xu, J.W., Zhong, J.J., 2011. Enhanced production of ganoderic acids in static liquid culture of Ganoderma lucidum under nitrogen-limiting conditions. Bioresour. Technol., 102(17):8185-8190. [doi:10.1016/j.biortech. 2011.06.043]

\section{中文概要}

\section{题 目: 利用液体发醉提高灵芝三萜产量及 HPLC-ESI-MS} 鉴定灵芝菌丝中灵芝酸成分

目 的: 通过优化液体发酵培养基提高灵芝三菬产量, 并 对其三萜成分进行初步鉴定。

创新点: 麦芽作为啤酒生产原料, 含有丰富的糖类及其他 营养物质, 并且价格低廉, 来源广泛。本文首次 将麦芽汁作为碳源物质以提高灵芝三萜产量, 并 对其所含灵芝酸成分进行初步鉴定。

方 法: 以灵芝菌丝生物量和胞内三萜产量为检测指标, 对其液体发酵培养基中的碳 $(\mathrm{C})$ 源和氮 $(\mathrm{N})$ 源 进行簰选, 并利用单因素实验确定其相应浓度, 再经响应面法优化液体发酵培养基 ( $\mathrm{C}$ 源、 $\mathrm{N}$ 源、 $\mathrm{pH}$ ）（表 1）。另一方面, 酸碱转化法纯化灵芝 三萜提取物后, 利用高效液相色谱-电喷雾-质谱 (HPLC-ESI-MS) 法初步鉴定灵芝所含灵芝酸成 分 (表 2)。

结 论: 本实验响应面结果显示: 当培养基含麦芽汁 4.1\%, 酵母浸出粉 $1.89 \%, \mathrm{pH}$ 为 5.40 时, 灵芝液体发 酵菌丝生物量及胞内三萜产量均达到最优, 分别 为 $1.87 \mathrm{~g} / 100 \mathrm{ml}$ 和 $93.21 \mathrm{mg} / 100 \mathrm{ml}$ 。经 HPLCESI-MS 鉴定, 初步确定其含有 10 种灵芝酸成分。

关键词: 灵芝; 麦芽汁; 响应面; 灵芝酸; 高效液相色谱电喷雾-质谱 (HPLC-ESI-MS) 